\title{
RESTORED CONFIDENCE IN IOWA BANKS
}

\section{By J. H. REDMAN}

[In response to request from The ANNALs editor, Mr. Newton P. Black, the present superintendent of banking in Iowa, recently reappointed, has co-operated in preparation of an analysis of the operation of the new Iowa banking law and the management of Iowa chartered banks by the state banking department. It was compiled especially for this publication by Mr. J. H. Redman, assistant to the superintendent, prior to his resignation from his position in the department since the turn of the year to enter duties as an official of a banking institution at Glidden, Iowa, and presents a comprehensive and most favorable showing of accomplishment.]

The Forty-fifth General Assembly of the state of Iowa passed legislation which provided for management of Iowa chartered banks by the state superintendent of banking upon application by the officers or directors for him to do so. This bill was known as Senate File 111 and even still is commonly referred to under this heading by Iowa bankers though it has since been codified under Sections 528.90 through 528.94.

The effective date of this act was January 23, 1933. Several banks made use of this legislation and the superintendent of banking was asked to take over the management prior to the national banking holiday, which was declared on March 4, 1933. Following the declaration of the holiday it was necessary that all active banks apply to the superintendent of banking for a release to operate their banks without restrictions or apply to the superintendent asking him to assume the management of the bank-for a maximum period of two years.

On the effective date of this act there were 628 active Iowa chartered banks, this number remaining the same until the time of the holiday. Following the holiday, 211 banks were released to operate without restrictions; 48 banks were released to operate under depositors agreements which had been made prior to this legislation; ten were voluntarily liquidated by officers and directors and the depositors were paid out $100 \%$; the remaining 359 banks were placed under S. F. 111. 
Of these 359 banks, 245 were released after securing waivers under depositors' agreements, 70 of these banks were liquidated through receivership, and 44 of them were recapitalized or sold, in full or in part.

In only one instance of record has a bank applied for management by the superintendent of banking under this statute since the national banking holiday, and that was due to defalcation by the bank management.

Under this act and other contemporary legislation there were created 274 depositors' trusts. These trusts were created through agreements between the subject banks and their depositors, whereby a certain percentage of the deposit was made immediately available to them or released to them at different intervals over a period of one or two years; the balance of the deposit was turned over to a group of trustees and certain slow and doubtful assets of the bank were turned over to them as an offset. The trustees were charged with the responsibility of the orderly liquidation of these assets and were to serve without compensation. The proceeds of these liquidations were paid to the depositors as liquidating dividends. In some cases assessments were collected from the stockholders and turned over to the trustees to be paid out as dividends to the depositors as an offset for anticipated losses in the segregated assets. In other instances a pledge of earnings was made by the subject banks to be used for the same purpose.

Some of these trusts were completely liquidated by the trustees, others were partially liquidated by the trustees and then turned over to the receivership division under the superintendent of banking for final liquidation. Some of these trusts were paid out in full at an early date, others paid out in full over a longer period, and still others did not fully repay the depositors.

At the present time-December, 1948-there are only five active trusts which are not fully liquidated, but it is anticipated that the final pay-out on these will be completed in the near future. 


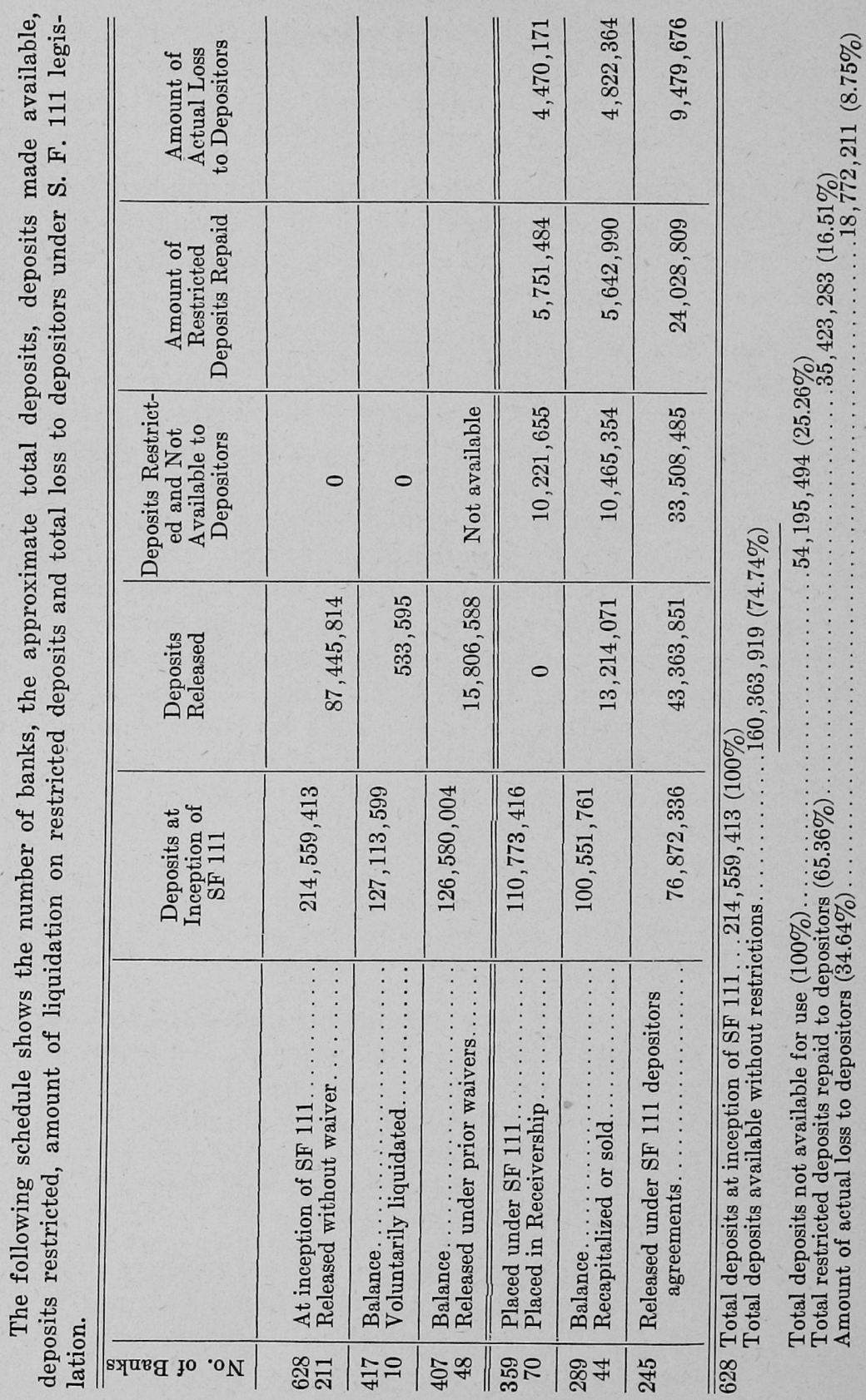




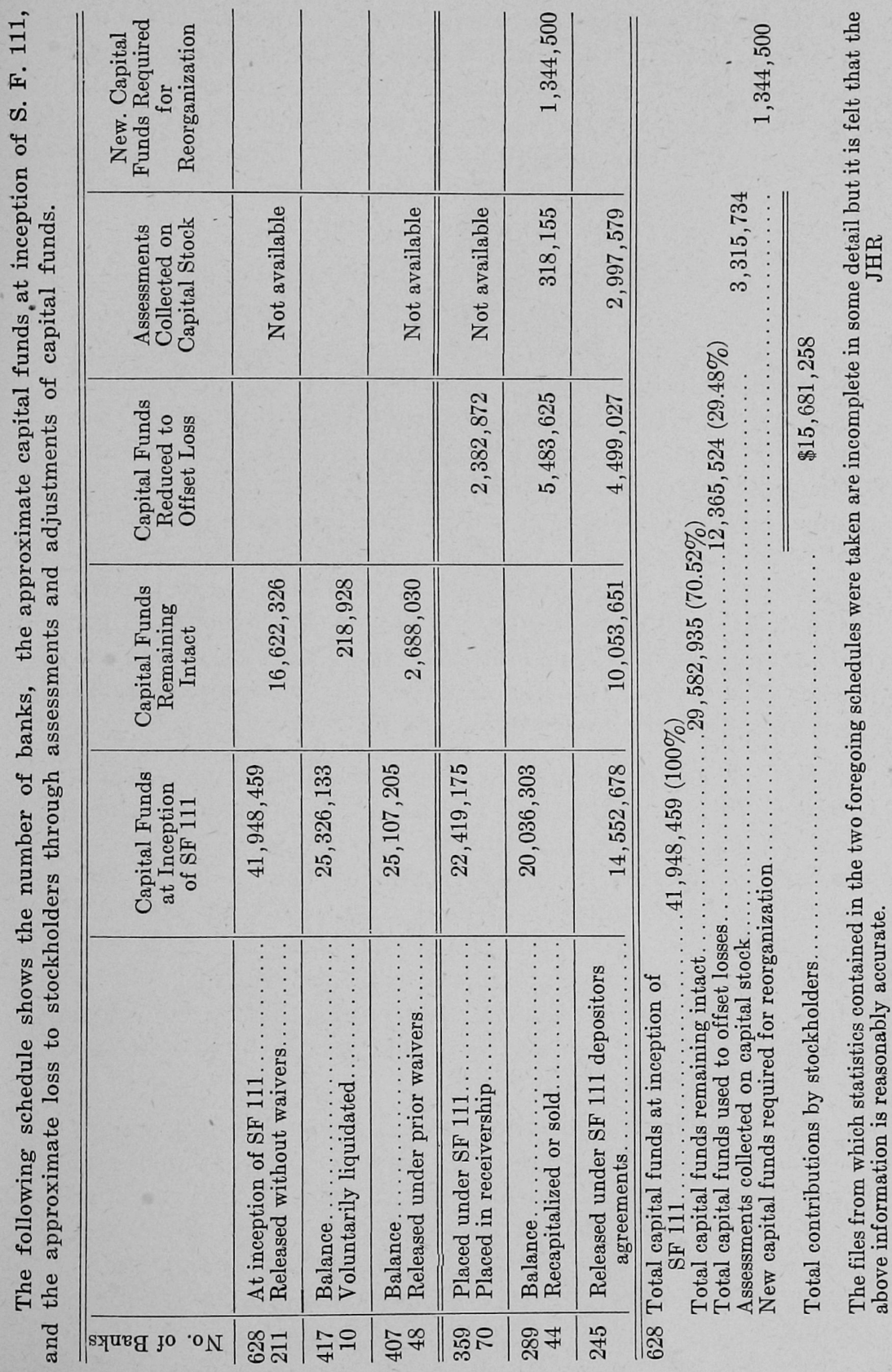


Under these same statutes some banks asked their depositors to waive their entire deposits for a certain period of time, funds to be released at intervals over a period or two or three years. Most of this type of waiver were taken before the passage of S. F. 111, and some banks that had taken these waivers were immediately released under these agreements after the holiday.

\section{Low Percentage of Depositor Loss}

The foregoing tabular report covers information concerning the 628 Iowa chartered banks which were in existence on January 23, 1933, date of the inception of Senate File 111 legislation, from that date up to the present time. It should be borne in mind that on June 30,1921 there were 1,350 Iowa chartered banks operating and the closings, consolidations and liquidations of the 722 banks representing the difference in total number of banks over this eleven and a half years period, from June 1921 to January 1933, is not accounted for in this survey. Unquestionably the losses to depositors and stockholders during that period were considerably greater than the losses shown in this report.

S. F. 111 legislation, had it been adopted earlier, might have eliminated the loss of some of the banks which were liquidated during this earlier period to which we refer. However, it is also surmised that a large proportion of this number of banks were so over extended on credit and so low on reserves that even the benefit of this legislation would have been of no avail. Therefore we can assume that certain banks that were forced into liquidation prior to S. F. 111 would have received no benefit from it, anyway.

S. F. 111 legislation did serve the purpose of stopping indiscriminate, wholesale, and panic inspired "runs" and "drains" on the remaining banks where such lack of confidence was unjustified and was causing solvent banks to enter into forced liquidation of sound assets (some of them at a loss) to meet depositors demands for cash. 
The statistics indicate that the losses suffered by depositors after the adoption of S. F. 111 were nominal and amounted to only $8.75 \%$ of the total deposits of all 628 banks. This small percentage of loss was, of course, made possible because of the opportunity for orderly liquidation of slow or doubtful assets under the benefits of this legislation.

The statistics further indicate that the stockholders' losses were approximately equal to the amount of the depositors' losses, which is a fact that has probably never been emphasized nor has it been realized by depositors. On the other hand, the losses as taken by stockholders in the still existing banks have in most cases been recuperated by them through earnings on their stock.

Without question, S. F. 111 legislation was thoughtfully prepared, highly effective and well administered. Without it further disastrous losses could not have been avoided. While these statutes have not been used or needed for several years a period of depression, panic and hysteria could again develop at some future time when these laws could again be used even more effectively than they were before.

\section{REBEL COLONEL AND YANKEE GENERAL}

When wars come too closely together, and there has been some shifting of patriotic cleavage, oftentimes there follows embarrassment to individual combatants, who remain sincere and are not conscious of any inconsistency in the changed course of their lives. Strong adherence to earlier convictions, and devotion to his ideals, but later yielding to the claims of a common cause and obedience to authority, was exemplified most notably in the useful career of former Gov. William Calvin Oates, of Alabama, who first served in the Fifteenth Alabama regiment of infantry in the Confederate army. Leading his command bravely in more than twenty-five battles he fought his way to a colonelcy, his dashing competency culminating in brilliant, though futile work at 
Gettysburg. Later he gave his right arm in the conflict at Petersburg, which prevented him from becoming a brigadier general in the Confederate army.

Returning to his law office to resume his place in civil life, he was sent to the Alabama legislature, and later became a member of his state's constitutional convention. Afterward he went on to congress as one of the state's representatives, and was returned six times as such. In 1894 he was elected governor of Alabama.

But, he was not destined to remain long in private life; for on April 19, 1898, the anniversary of the battle of Lexington, 1775, the United States declared war on Spain. The U. S. regular army was not sufficient in size or strength to wage vigorous combat. But, volunteers flocked to the colors, and the national guard was inducted into the army. Major William McKinley seeking experienced military talent to command the volunteer armies then stepped across the old lines of sectional strife, and William C. Oates became a brigadier general of the United States volunteers.

In accepting his new military rank, the old Confederate colonel who had so often led his forces against the United States army, said:

"Times change and we change with them. I believed implicity in the rightousness of the cause of the Confederacy, and served it to the best of my ability until it went down in smoke and blood. The United States is now my government, and with my one arm I will serve as faithfully as I did the Confederacy. I now don the uniform and wave the flag upon which many times from 1861 to 1865 I ordered my command to fire. I am now a Yankee general, formerly a Rebel colonel, and right each time!"

Although the war did not last long, General Oates commanded three different brigades, each composed largely of soldiers from northern states, and they too learned to love and respect the old warrior from Alabama. His son, William C. Oates, Jr., served as a captain in World War I, and upon his return home was elected commander of the local post of the American Legion. 
Copyright of Annals of Iowa is the property of State of Iowa, by \& through the State Historical Society of Iowa and its content may not be copied or emailed to multiple sites or posted to a listserv without the copyright holder's express written permission. However, users may print, download, or email articles for individual use. 